\title{
Cytogenetic characterization of the silverside fish Odontesthes regia (Humboldt, 1833) (Teleostei: Atheriniformes: Atherinopsidae) from Iquique, Chile
}

\author{
Caracterización citogenética del pejerrey Odonthesthes regia (Humboldt, 1833) \\ (Teleostei: Atheriniformes: Atherinopsidae) de Iquique, Chile \\ Carlos Muñoz ${ }^{1}$, Mauro Nirchio²*, Julio E. Pérez ${ }^{3}$, Ernesto Ron ${ }^{2}$ \\ Claudio Oliveira ${ }^{4}$ and Irani A. Ferreira ${ }^{4}$ \\ ${ }^{1}$ Departamento de Ciencias del Mar, Universidad Arturo Prat, Iquique, Chile, Casilla $N^{o} 121$ \\ ${ }^{2}$ Escuela de Ciencias Aplicadas del Mar. Universidad de Oriente, Isla de Margarita, Venezuela, Apartado Postal 147 \\ ${ }^{3}$ Instituto Oceanográfico de Venezuela, Universidad de Oriente, Cumaná, Venezuela \\ ${ }^{4}$ Departamento de Morfologia, Instituto de Biociências, Universidade Estadual Paulista, 18618-000 Botucatu, São Paulo, Brazil \\ nirchio@cantv.net
}

\begin{abstract}
This paper describes the karyotype of Odontesthes regia by means of Giemsa staining, C-banding, to reveal the distribution of the constitutive heterochromatin, and by Ag-staining and fluorescent in situ hybridization (FISH), to locate ribosomal genes (rDNA). The chromosome diploid modal count in the species was $2 \mathrm{n}=48$. The karyotype is composed of one submetacentric pair (pair 1), 16 subtelocentric pairs (pairs 2 to 17), and 7 acrocentric pairs (pairs 18 to 24). With the exception of pair 1 it was not possible to classify the homologous chromosomes accurately because differences in chromosome size were too slight between adjacent pairs. The distribution of C-banded heterochromatin allowed for a more accurate matching of the majority of chromosomes of the subtelocentric series. Silver staining of metaphase spreads allowed for the identification of Nucleolus Organizer Regions (Ag-NOR) on pair 1. FISH experiments showed that $18 \mathrm{~S}$ rDNA sequences were located, as expected, in the same chromosome pair identified as the Ag-NOR-bearing one.
\end{abstract}

Key words: Karyotype, NOR, C-bands, FISH
Resumen.- Este trabajo describe el cariotipo de Odonthestes regia, por medio de tinción Giemsa, bandeo C, para revelar la distribución de la heterocromatina constitutiva, y por medio de tinción con nitrato de plata e hibridación fluorescente in situ (FISH), para localizar genes ribosomales (rADN). El recuento modal cromosómico diploide en la especie fue de $2 n=48$. El cariotipo está compuesto por un par submetacéntrico (par 1), 16 pares subtelocéntricos (pares 2 al 17) y 7 pares acrocéntricos (pares 18 al 24). Con excepción del par 1, no fue posible clasificar con exactitud a los cromosomas homólogos, ya que las diferencias en el tamaño fueron muy pequeñas entre pares adyacentes. La distribución de la heterocromatina por bandeo C permitió aparear a la mayoría de los cromosomas de la serie subtelocéntrica. La tinción con plata de preparaciones metafásicas permitió la identificación de las regiones organizadoras del nucléolo (AgRON) en el par 1. Los experimentos FISH mostraron que las secuencias $\mathrm{ADNr} 18 \mathrm{~S}$ estaban localizadas, como era de esperar, en el mismo par cromosómico identificado como los portadores de Ag-RON.

Palabras clave: Cariotipo, RON, bandeo-C, FISH

\section{Introduction}

The great importance of conservation biology and the need to develop new tools that allow understanding ecosystems, phyletic relationship among taxa and identification of new species, has encouraged scientists to perform new karyological studies in fishes.

Cytogenetic studies of fishes from the South American continent have displayed a considerable expansion in the last years. To date cytogenetic data for 47 families, 278 genera and 1,047 freshwater species and 39 families, 73 genera and 109 marine species are registered (Nirchio \& Oliveira 2006), but for Chile, few karyological studies of fish, in relation with its richness, specially of marine fishes, have been carried out. Among these studies, the contribution of the late Dr. Hugo Campos is of great importance (Arratia \& Campos $1997^{1}$, Campos 1972, Cuevas et al. 1999,

\footnotetext{
${ }^{1}$ Arratia G \& HH Campos. 1997. Karyotypes of Diplomystid and certain loricarioid catfishes. International Symposium on Phylogeny and Classification of Neotropical Fishes The Neotropical Ichthyological Association, Porto Alegre, Brazil
} 
Table 1

Chromosome data of Atheriniformes

Datos cromosómicos de Atheriformes

\begin{tabular}{|c|c|c|c|c|}
\hline Species & $2 n$ & NF & Karyotype formula & Reference \\
\hline Atherion elymus & 48 & 50 & $2 \mathrm{SM}+10 \mathrm{ST}+36 \mathrm{~A}$ & Arai \& Fujiki (1978) \\
\hline Atherina monchon & 48 & 54 & $6 S M+42$ ST-A & Vasiliev $(1980,1985)$ \\
\hline Basilichthys australis & 48 & 57 & $4 M+5 S M+39 S T-A$ & Gajardo (1992) \\
\hline B. banariensis & 48 & 52 & $4 \mathrm{M}+44 \mathrm{ST}-\mathrm{A}$ & Arai \& Koike (1980) \\
\hline B. microlepidotus & 46 & 62 & $2 \mathrm{M}+14 \mathrm{SM}+30 \mathrm{ST}-\mathrm{A}$ & Gajardo (1992) \\
\hline Bedotia geayi & 48 & 72 & & Scheel (1972) in Klinkhardt et al. (1995) \\
\hline Chirostoma attenuatum & 48 & $76 a$ & $4 \mathrm{M}+24 \mathrm{SM}+2 \mathrm{ST}+18 \mathrm{~A}$ & Alvarez-Espíndola (1994) \\
\hline C. estor & 48 & 68 & $12 \mathrm{M}+8 \mathrm{SM}+12 \mathrm{ST}+16 \mathrm{~A}$ & Uribe-Alcocer et al. (2002) \\
\hline C. jordani & 48 & 68 & $8 \mathrm{M}+12 \mathrm{SM}+10 \mathrm{ST}+18 \mathrm{~A}$ & Uribe-Alcocer et al. (2002) \\
\hline C. patzcuaro & 44 & 44 & $12 \mathrm{ST}+32 \mathrm{~A}$ & Uribe-Alcocer et al. (2002) \\
\hline C. grandocule & 48 & & & Durán-González et al. (1997) \\
\hline Labidesthes sicculus & 48 & 82 & $12 \mathrm{M}+22 \mathrm{SM}+14 \mathrm{ST}-\mathrm{A}$ & Korth \& Fitszimons (1987) \\
\hline Membras martinico & 48 & 84 & $18 \mathrm{M}+18 \mathrm{SM}+12 \mathrm{ST}-\mathrm{A}$ & Korth \& Fitszimons (1987) \\
\hline Menidia berilina & 48 & 74 & $8 \mathrm{M}+18 \mathrm{SM}+22 \mathrm{ST}-\mathrm{A}$ & Korth \& Fitszimons (1987) \\
\hline M. berilina & 48 & 82 & $10 \mathrm{M}+24 \mathrm{SM}+14 \mathrm{ST}-\mathrm{A}$ & Korth \& Fitszimons (1987) \\
\hline M. mendia & 48 & 66 & $4 \mathrm{M}+14 \mathrm{SM}+12 \mathrm{ST}+18 \mathrm{~A}$ & Warkentine et al. (1987) \\
\hline Odontesthes bonariensis & 48 & 52 & $4 \mathrm{SM}+44+46 \mathrm{ST}$ & Sola et al. (1988) \\
\hline O. bonariensis & 48 & 52 & $4 \mathrm{SM}+44 \mathrm{ST}-\mathrm{A}$ & Arai \& Kioke (1980) \\
\hline O. regia & 48 & 50 & $2 \mathrm{SM}+32 \mathrm{ST}+14 \mathrm{~A}$ & Present study \\
\hline Telmatherina ladigesis & 48 & 86 & & Scheel (1972) in Klinkhardt et al. (1995) \\
\hline
\end{tabular}

Valenzuela et al. $1992^{2}$, Campos et al. $1995^{3}$ ). A recent paper by Winkler et al. (2004) described the karyotype of three species of flounders from Chile.

Odontesthes regia (Humboldt, 1833) (Teleostei: Atheriniformes) belongs to the Atherinopsidae family and is locally known as "pejerrey" or "pejerrey marino," and internationally as "sea silverside." This is an epipelagic species distributed from the north Pacific coast of Peru to the Aysen region, in Chile (Dyer 2000). The species has great economic importance as a fresh staple food (Froese \& Pauly 2005). Although the

\footnotetext{
2 Valenzuela AC, HF Alay, EJ Gavilan \& CH Campos 1992. Contribución al estudio citogenético de peces dulceacuícolas en Chile: Los cromosomas somáticos de Cheirodon galusdae, C. australae y Percichthys trucha. XXV Reunión anual Sociedad de Genética de Chile, La Serena, Chile, 26-29 de agosto, 1992 (http://www.conicyt.cl/bases/bibfon/0/0/920200.html)

3 Campos CH, C Cuevas \& EJ Gavilán. 1995. Cariotipos de Aplochiton zebra y Aplochiton taeniatus (Pisces: Salmoniformes). Proyecto FONDECYT: 92/0200.

(http://www.conicyt.cl/bases/bibfon/0/0/920200.html)
}

family Atherinopsidae includes 104 species (13 genera), only 17 species have been cytogenetically studied to date (Table 1), demonstrating that cytogenetic studies in this group are still scarce.

As part of a project to study the cytogenetic biodiversity of the Chilean ichthyofauna, this paper is the first report of the karyotype of $O$. regia from Iquique, Chile by means of Giemsa staining, C-banding, silver staining to locate active Nucleolus Organizing Regions (NORs), and FISH to locate the NOR cistrons on the chromosomes.

\section{Materials and methods}

A sample comprising five specimens (2 females and 3 males) of $O$. regia was analyzed. Specimens were seined off the coast of Iquique Bay (20 ${ }^{\circ} 10.15^{\prime} \mathrm{S}$ $\left.70^{\circ} 10.18^{\prime} \mathrm{W}\right)$. Voucher specimens were kept at the fish collection of Departamento de Ciencias del Mar (MUAP-PO: 0893， 0894， 0895， 0896， 0897), Universidad Arturo Prat, Iquique, Chile. 
Chromosome preparations were carried out following the technique described by Bertollo et al. (1978). For the conventional karyotype, the preparations were stained for 20 minutes with $5 \%$ Giemsa in a phosphate buffer at $\mathrm{pH}$ 6.88. C-bands were obtained according to Sumner (1972). Detection of the Nucleolus Organizer Regions (NORs) was carried out following the silver staining method of Howell \& Black (1980), and by FISH according Pinkel et al. (1986). A tilapia (Oreochromis niloticus) 18S rDNA sequence (about 1,800 base pairs) cloned in pGEM-T was labeled by nick translation with biotin-14-dATP according to the manufacturer instructions (Bionick ${ }^{\mathrm{TM}}$ Labelling System-Gibco. BRL). The $18 \mathrm{~S}$ rDNA sequences were located in the chromosomes by Avidin-N-fluorescein Isothiocyanate (FITC) conjugate, and the signal was enhanced by using biotinilated Anti-avidin goat antibodies following a second round of the Avidin-FITC detection. Chromosomes were counter-stained with Propidium Iodide $(50 \mu \mathrm{g} / \mathrm{ml})$ diluted in Antifade.

Mitotic chromosomes were photographed using a digital camera and images were digitally processed with Adobe Photoshop v. 7.0. The karyogram was constructed with chromosomes organized in sizedecreasing order. Chromosomes were classified following Levan et al. (1964). Metaphases analyzed by FISH were examined in a Zeiss Axiophot photomicroscope and pictures were taken with a Kodak Gold Ultra 400 ASA film.

\section{Results and discussion}

Chromosome diploid modal count was $2 \mathrm{n}=48$, obtained in $82 \%$ of all the (107) cells examined. The representative karyogram for the species is shown in Fig. 1A. The karyotype of this species consists of one submetacentric pair (pair 1), 16 subtelocentric pairs (pairs 2 to 17), and 7 acrocentric pairs (pairs 18 to 24). With the exception of pair 1 , it was not possible to carry out an accurate classification of chromosomes as homologous pairs due to their similar morphology and slight differences in chromosome size.

According to the most recent review of fish chromosome data, $11.5 \%$ of the extant fish species possess a karyotype with $2 \mathrm{n}=48$ and a variable Fundamental Number (FN) (Klinkhardt et al. 1995). A recent study (Miya et al. 2003) suggests that orders Atheriniformes, Cyprinodontiformes, and Beloniformes constitute a monophyletic group closely related to
Mugiliformes and some Perciformes. Considering that the most common diploid number found in Mugiliformes and Perciformes is $2 \mathrm{n}=48$ (Klinkhardt et al. 1995), it is possible to suggest that the presence of $2 \mathrm{n}=48$ chromosomes, as observed in $O$. regia, represents a primitive characteristic of the order Atheriniformes. Despite the conserved diploid number in the genus Odontesthes, a clear difference in chromosome formulae is observed between $O$. bonariensis and O. regia. Sola et al. (1988) and Arai \& Kioke (1980) reported the karyotype of $O$. bonariensis as possessing 48 chromosomes with 4 submetacentric and 44 subtelocentric-acrocentric and $\mathrm{FN}=52$, so determined by considering subtelocentric elements as uniarmed-chromosomes. If for comparative purposes we consider the subtelocentric chromosomes of $O$. regia as uniarmed, the species would have a $F N=50$, so the differences in chromosome formulae between these two species suggest that their karyotypes could have diverged by rearrangements involving a pericentric inversion to convert a subtelocentric chromosome into a submetacentric or into an acrocentric one, respectively (or vice versa) while at the same time keeping the numeric hypothetical chromosome condition $2 n=48$.

C-banded heterochromatin is distributed in a pericentromeric position in all chromosomes except a large positive interstitial band near the centromere in pair 6, and a large telomeric segments in chromosome pairs 3 and 7 . Such distribution of C-banded heterochromatin allows for a more accurate, tentatively homologous chromosome pairing in the majority of chromosomes of the subtelocentric series (Fig. 1B).

Silver staining revealed that the Ag-NOR clusters are localized on pair 1 with the Ag-NOR signal located on the tip of their short arms (Fig. 2). Sola et al. (1988) reported the single pair of NORs in $O$. bonariensis as terminal on the short arm of a small-sized submetacentric chromosome.

NOR-silver staining is one of the methods used to locate 18S and 28S rRNA cistrons in chromosomes (Howell \& Black 1980). Silver stainability of NORs requires transcriptional activity of the ribosomal genes during the preceding interphase (see Hubbel 1985, Sánchez-Pina et al. 1984, Jimenez et al. 1988), whereas FISH allows for the exact detection of the location and number of ribosomal genes in the chromosome complement. 


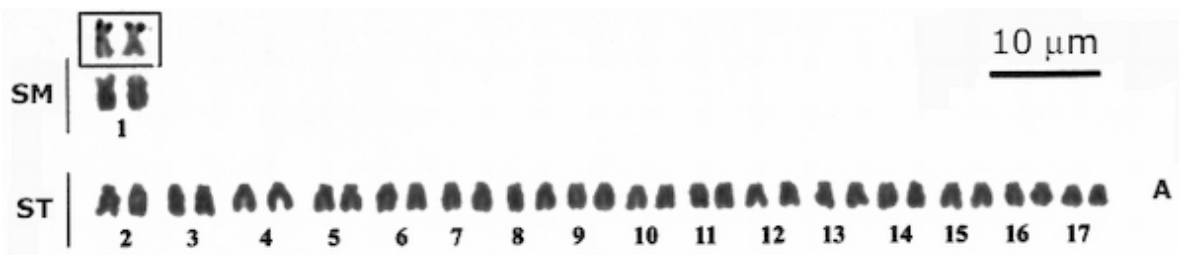

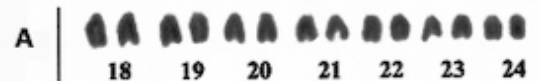

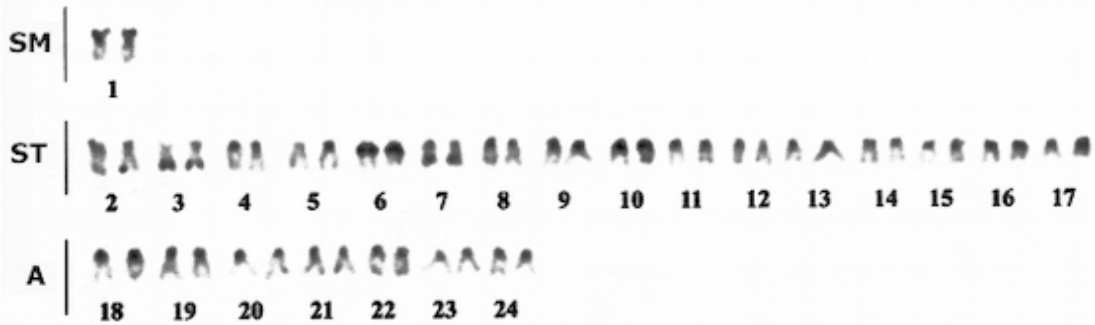

Figure 1

Cytogenetic characteristics of Odontesthes regia. (A) Giemsa stained karyotype. Above pair 1 the same chromosome pair stained with silver nitrate to show the Ag-NORs (black dots). (B) C-banded karyotypes

Características citogenéticas de Odontesthes regia. (A) Cariotipo teñido con Giemsa. Sobre el par 1, el mismo par de cromosomas teñido con nitrato de plata para mostrar las Ag-RON (puntos negros). (B) Cariotipos de bandeo C

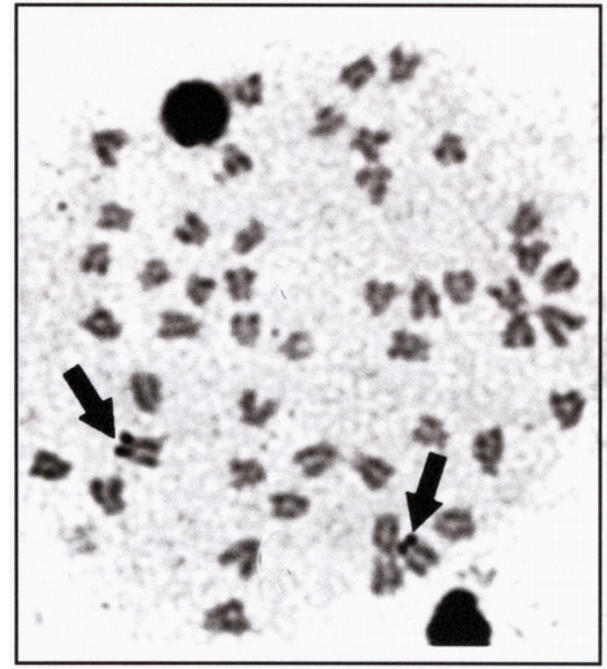

Figure 2

Silver-stained metaphase of Odontesthes regia showing AgNOR-bearing chromosomes (arrows)

Metafases de Odontesthes regia teñidas con plata mostrando los cromosomas que tienen Ag-RON (flechas)

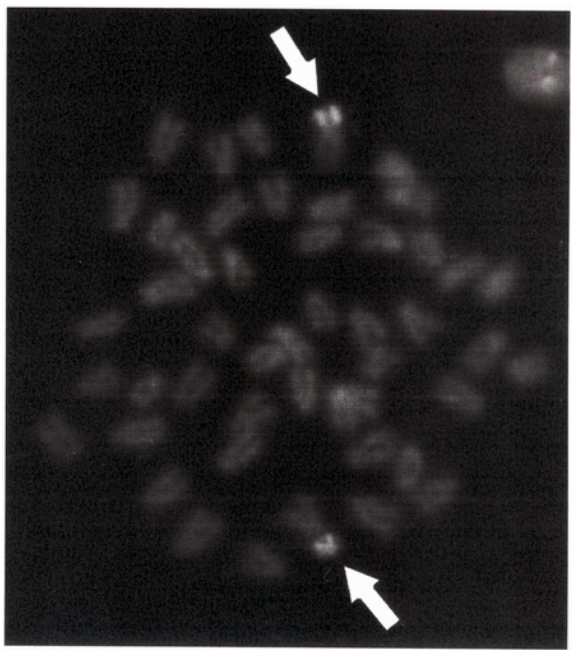

Figure 3

Metaphase of Odontesthes regia showing chromosomes after fluorescent in situ hybridization with the 18S rDNA gene. Arrows point out the 18S-bearing chromosomes

Metafase de Odontesthes regia mostrando los cromosomas después de hibridación fluorescente in situ con el gen $18 \mathrm{~S}$ rADN. Las flechas indican los cromosomas que llevan el 18S 
As far as ribosomic cistrons are concerned, the most frequent localization of NORs in fish chromosomes is terminal on a single chromosome pair (Galetti et al. 1984, Birstein \& Vasilev 1987, Klinkhardt et al. 1995), although some taxa exhibit multiple NORs (Foresti et al. 1981, Nirchio et al. 2002, Gaviria et al. 2005, Phillips et al. 1988, Castro et al. 1996). The use of FISH with $18 \mathrm{~S}$ rDNA probing is a technique extremely well suited to characterize a species; it allows researchers to know whether differences in Ag-NOR number are related only with the differential activities of these regions or with different numbers of NORs in the genome of different specimens (Gornung et al. 1997, Nirchio et al. 2003). The FISH experiments performed here show that $18 \mathrm{~S}$ rDNA signals coincide with signals seen in the Ag-NOR-bearing chromosomes (Fig. 3), indicating that $O$. regia does not possess additional NOR sites and that all NOR cistrons are active.

\section{Acknowledgments}

Consejo de Investigación of Universidad de Oriente (Venezuela), CNPq and FAPESP (Brazil) provided funds to support this study. We are gratefull to anonymous reviewers who contributed to the improvement of the final version of the manuscript

\section{Literature cited}

Alvarez-Espíndola MA. 1994. Estudio citogenético del charal prieto (Chirostoma attenatum) Meek, 1902 (Pisces: Atherinidae) en el Lago de Pátzcuaro, Michoacán. Tesis de Licenciatura, Facultad de Ciencias, Universidad Nacional Autónoma de México, México, D.F., 56 pp.

Arai R \& A Fujiki. 1978. Chromosomes of two species of atherinoid fishes. Bulletin of the National Science Museum (Ser. A) 4: 147-150.

Arai R \& A Kioke. 1980. A karyotype study on two species of freshwater fishes transplanted into Japan. Bulletin National Science Museum Tokyo (Zool.) 6: 275-278.

Bertollo LAC, CS Takahashi \& O Moreira-Filho. 1978. Cytotaxonomic considerations on Hoplias lacerdae (Pisces, Erythrinidae). Brazilian Journal of Genetics 1: 103-120.

Birstein VJ \& VP Asilev. 1987. Nucleolar organizer regions, their function and polyploidy in fishes. Journal Obshchej Biology 6: 729- 747.

Campos HH. 1972. Karyology of three galaxiid fishes Galaxias maculates, G. platei and Brachygalaxias bullocki. Copeia 1972 (2): 368-370.
Castro J, A Vinas, Al Sanchez \& IA Martinez. 1996. Characterization of an atypical NOR-site polymorphism in brown trout (Salmo trutta) with Ag- and CMA3-staining, and fluorescent in situ hybridization. Cytogenetics and Cell Genetics 75: 234-239.

Clavaguera A, E Querol, C Dolors, J Genesca \& J Egozcue. 1983. Cytochemical studies on the nature of NOR (nucleolus organizer region) silver stainability. Cellular and Molecular Biology 29: 255-259.

Cuevas CC, HH Campos \& K Busse, 1999. Cytotaxonomic studies on Chilean galaxiid fishes. The karyotypes, Cbands, Ag-NORs and hybrids of Brachygalaxias gothei and B. bullocki (Osteichthyes: Galaxiidae). Cytologia 64: 379-385.

Durán-González A, A Laguarda-Figueras, C GarcíaRuelas. 1997. Estudio citogenético del charal blanco Chirostoma grandocule (Steindachner) del Lago de Pátzcuaro, Michoacán. Memorias del XIV Congreso Nacional de Zoología. Guanajuato, México, p. 35.

Dyer B. 2000. Revisión sistemática de los pejerreyes de Chile (Teleostei, Atheriniformes). Estudios Oceanológicos 19: 99-127.

Foresti F, LF Almeida-Toledo \& SA Toledo-Filho. 1981. Polymorphic nature of nucleolus organizer regions in fishes. Cytogenetics and Cell Genetics 31: 137-144.

Froese R \& D Pauly. 2005. FishBase. www.fishbase.org, (visited 06/2005).

Gajardo GM. 1992. Karyotypes of Basilichthys microlepidotus and B. australis (Pisces: Atherinidae). Copeia 256-258.

Galetti PM, F Foresti, LAC Bertollo \& O Moreira-Filho. 1984. Characterization of eight species of Anostomidae (Cypriniformes) fish on the basis of nucleolar organizing regions. Caryologia 37: 401-406.

Gaviria JI, M Nirchio, A Granado \& A Estrada. 2005. Karyotype and nucleolar organizer regions of Pygocentrus cariba (Humboldt, 1821) (Pisces: Serrasalminae) from Caicara del Orinoco, Venezuela, Interciencia 30 (1): 44-47

Gold JR. 1984. Silver-staining and heteromorphism of chromosomal nucleolus organizer regions in North American cyprinid fishes. Copeia 1:133-139.

Gornung E, I Gabrielli, C Stefano \& L Sola. 1997. CMA3banding pattern and fluorescence in situ hybridization with 18S rRNA genes in zebrafish chromosomes. Chromosome Research 5: 40-546.

Howell Wm \& Da Black. 1980. Controlled silver staining of Nucleolus Organizer Regions with a protective colloidal developer: a 1-step method. Experientia 36: 1014-1015. 
Hubbel HR. 1985. Silver staining as an indicator of active ribosomal genes. Stain Technology 60: 285-294.

Jiménez R, M Burgos \& R Diaz de La Guardia. 1988. A study of the silver staining significance in mitotic NORs. Heredity 60: 125-127.

Klinkhardt M, M Tesche \& H Greven. 1995. Database of fish chromosomes. Westarp Wissenschaften, Magdeburg, Germany, 237 pp.

Korth JW \& JM Fitzsimons. 1987. Karyology of three species of Eastern North American Atherinid fishes. Copeia: 505-509.

Levan A, K Fredga \& A Sandberg. 1964. Nomenclature for centrometric position on chromosomes. Hereditas 52: 201220.

Medina FJ, MC Risueño, MA Sánchez-Pina \& ME Fernández-Gómez. 1983. A study on nucleolar silver staining in plant cells. The role of argyrophylic proteins in nucleolar physiology. Chromosoma 88: 149-155.

Miya M, H Takeshima, H Endo, NB Ishiguro, JG Inoue, T Mukai, TP Satoh, M Yamaguchi, A Kawaguchi, K Mabuchi, SM Shira \& M Nishida. 2003. Major patterns of higher teleostean phylogenies: a new perspective based on 100 complete mitochondrial DNA sequences. Molecular Phylogenetics and Evolution 26: 121-138.

Nelson JS. 1994. Fishes of the world. $3^{\text {rd }}$ ed, 600 pp. John Wiley \& Sons, Inc., New York, USA.

Nirchio M \& C Oliveira. 2006. Citogenética de peces, 216 pp. Universidad de Oriente, Cumaná, Venezuela, 216 pp.

Nirchio M, A Granado, E Ron \& JE Pérez. 2002. Karyotype and Nucleolar Organizer Regions in Serrasalmus rhombeus (Linneaus, 1766) (Serrasalminae) from Caicara Del Orinoco, Venezuela. Interciencia 27(12): 676-678.

Nirchio M, AS Fenocchio, AC Swarça, JE Pérez, A Granado, A Estrada \& E Ron. 2003. Cytogenetic characterization of hybrids offspring between Colossoma macropomum (Cuvier, 1818) and Piaractus brachypomus (Cuvier, 1817) from Caicara del Orinoco, Venezuela. Caryologia 56(4): 405-411.
Phillips RB, KA Pleyte \& SE Hartley. 1988. Stock-specifc differences in the number and chromosome positions of the nucleolar regions in Arctic charr (Salvelinus alpinus). Cytogenetics and Cell Genetics 48: 9-12.

Pinkel D, T Straume \& JW Gray. 1986. Cytogenetic analysis using quantitative, high-sensitivity, fluorescence hybridization. Proceedings of the National Academy of Sciences 83: 2934-2938.

Sánchez-Pina MA, FJ Medina, MM Fernández-Gómez \& MC Risueno. 1984. Ag-NOR proteins are present when transcription is impaired. Biology of the Cell 5: 199-202.

Sola L, GL Natili \& S Cataudella. 1988. Cytogenetical characterization of Odontesthes bonariensis (Pisces, Atherinidae), an Argentine species introduced in Italy. Genetica 77: 217-224.

Sumner AT. 1972. A simple technique for demonstrating centromeric heterocromatin. Experimental Cell Research 75: 304-306.

Uribe-Alcocer M, H Olvera-García \& P Díaz-Jaimes. 2002. Karyotype analysis in three species of the genus Chirostoma (Atheriniformes: Atherinidae). Ichthyological Research 49: 85-88.

Vasiliev VP. 1980. Chrnosomnye tschisla ryboobrasnych i ryb. Voprosi Ikhtiologii 20: 387-422.

Vasiliev VP. 1985. Evoljuzionnaja kariologiya ryb, 300 pp. Nauka, Moscow.

Warkentine BE, CL Smith \& JW Rachlin. 1987. A reevaluation of the karyotype of the Atlantic silverside, Menidia menidia. Copeia 1987: 222-224.

Winkler FM, D Garcia-Melys \& C Alma-Rojas. 2004. Karyotypes of three South East Pacific flounder species of the family Paralichthyidae. Aquaculture Research 35: 1295-1298 